\title{
ST
}

Science \& Technology

PAPER - OPEN ACCESS

Implementasi Model Pembelajaran Berbasis Masalah Menggunakan Powerpoint Materi Stoikiometri Untuk Menigkatkan Hasil Belajar Siswa

$\begin{array}{ll}\text { Author } & : \text { Frensi Hasanah dkk., } \\ \text { DOI } & : 10.32734 / \text { st.v2i1.358 } \\ \text { Electronic ISSN } & : 2654-7082 \\ \text { Print ISSN } & : 2654-7074\end{array}$

Volume 2 Issue 1 - 2018 TALENTA Conference Series: Science \& Technology (ST)

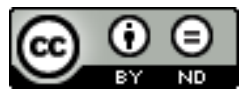

This work is licensed under a Creative Commons Attribution-NoDerivatives 4.0 International License.

Published under licence by TALENTA Publisher, Universitas Sumatera Utara

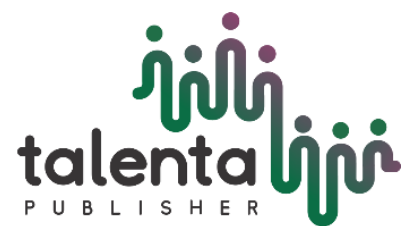




\title{
inili (2) \\ TM Conference Series 02 (2019)

\section{Implementasi Model Pembelajaran Berbasis Masalah Menggunakan Powerpoint Materi Stoikiometri Untuk Menigkatkan Hasil Belajar Siswa}

\author{
Frensi Hasanah ${ }^{\mathrm{a} *}$, Mahmud $^{\mathrm{b}}$, Risky Hikmi ${ }^{\mathrm{c}}$ \\ ${ }^{a}$ Program Studi Pendidikan Kimia, Pascasarjana, Universitas Negeri Medan, Medan \\ ${ }^{b}$ Jurusan Kimia, Fakultas MIPA, Universitas Negeri Medan, Medan \\ 'Program Studi Pendidikan Kimia, Pascasarjana, Universitas Negeri Medan, Medan \\ *frensihasanah@gmail.com
}

\begin{abstract}
Abstrak
Tujuan penelitian ini yaitu, untuk mengetahui hasil belajar kimia pada siswa yng dibelajrkan dengan menerapkan model pembelajaran berbasis masalah dengan menggunakan media powerpoint lebih tinggi daripada siswa yang dibelajarkan dengan menggunakan konvensional pada materi Stoikiometri. Dalam penelitian ini populasinya yaitu seluruh siswa kelas X MIA SMA NEGERI 1 STABAT semester genap, tahun ajaran 2014/2015 sebanyak \pm 250 orang siswa, yang terdiri dari 6 kelas. Sedangkan sampel dalam penelitian ini sebanyak 2 kelas diambil secara purposive. Penelitian ini merupakan jenis eksperimental. Dari analisis data perhitungan diperoleh dari penelitian yang telah dilaksanakan, mengalami peningkatan hasil belajar kimia pada siswa yang dibelajarkan dengan menerapkan model pembelajaran berbasis masalah dengan menggunakan media powerpoint dengan hasil yang lebih tinggi yaitu $83 \%$, sedangkan pada siswa yang dibelajarkan dengan pembelajaran konvensional yaitu, 69\%. Maka hasil pebedaan peningkatan hasil belajar siswa pada kelas eksperimen dengan kelas kontrol adalah $14 \%$.
\end{abstract}

Kata Kunci : Model Pembelajaran Berbasis Masalah, Stoikiometeri, Powerpoint

\section{Pendahuluan}

Pendidkan di Indonesia terus mengalami perubahan dan perkembangan seiring dengan perkembangan dunia global. Banyak usaha yang dilakukan salah satunya adalah dengan menyempurnakan kurikulum [10]. Pemerintah telah berupaya untuk menerapkan dan mengembangkan kurikulum berbasisi kompetensi pada tahun 2004 dan 2006 menjadi kurikulum 2013. Dimana diketahui bahwa kurikulum 2013 berfokus pada kegiatan aktif siswa melalui suatu proses ilmiah dengan tujuan agar pembelajaran tidak hanya menciptakan peserta didik yang memiliki kompetensi pengetahuan saja, tetapi juga mampu menciptakan peserta didik memiliki siakp dan keterampilan yang baik[1].

Ilmu Pengetahuan Alam sangat berkaitan dengan cara mencari tahu tentang alam secara sistematis, sehingga IPA bukan hanya penguasaan kumpulan pengetahuan yang berupa fakta - fakta, konsep - konsep atau prinsip prinsip saja tetapi juga merupakan suatu proses penemuan [11]. Sama halnya dengan Kimia yang merupakan bagaian dari IPA. Kimia merupakan mata pelajaran yang sarat mulai dari konsep yang sederhana sampai dengan konsep yang lebih kompleks sehingga sangatlah diperlukan pemahaman yang sangat baik terhadap konsep dasar kimia[2].

Materi pada semester genap di kelas X MIA salah satunya yaitu Stoikiometri. Pada bab materi Stoikiometri terdapat konsep, yang dibutuh pemahaman, karena materi ini akan terus dipelajari sampai kelas XII MIA. Materi ini membutuhkan daya pemahaman yang baik, karena siswa akan dikenalkan pada macam-macam rumus dan hubungan rumus yang satu dengan yang lain. Oleh karena itu diperlukan keaktifan dalam kegiatan pembelajaran tidak hanya terpusat oleh guru dan perlunya belajar dalam kelompok untuk mencapai hasil pembelajaran yang baik [3].

Setelah dilaksanakan observasi awal peneliti di Sekolah Menegah Atas Negeri 1 Stabat, peneliti melaksanakan 
wawancara kepada guru kimia dan beberapa peserta didik mengenai bagaiman mendapat mereka terhadap mata pelejaran kimia dan terkhusus pada materi Stoikiometri. Dari hasil wawancara banyak peserta didik yang mengatakan materi kimia sulit untuk dipahami. Kondisi ini sangat berpengaruh dengan hasil belajar para peserta didik yang masih rendah.

Terdapat beberapa faktor penyebab tidak optimalnya hasil belajar yang didapat peserta didik diantaranya yaitu, guru tidak menggunakan model, strategi, maupun media dalam proses pembelajaran dengan tepat, guru mengajar masih dengan cara konvensional. Dalam hal ini guru berperan sebagai sumber informasi utama dan sanagat dominan dalam proses belajar mengajar. Sehingga membuat peserta didik menjadi pasif, peserta didik cenderung belajar dengan cara menghafal dan tidak membangun sendri penegtahuannya hal ini mengakibatkan peserta didik kurang berkembang. Kondisi yang telah terjadi tidak mendukung dalam peningkatan kemampuan untuk memecahkan masalah[2].

Pemerintah telah berusaha melakukan perubahan dan perbaikan dengan perbaikan kurikulum sehingga muncul kurikulum 2013. Pada kurikulum ini proses belajar mengajar menggunakan pendekatan saintifik yang terdapat karakter didalamnya salah satunya materi pembelajaran berbasis fakta atau fenomena yang dapat dijelaskan dengan logika serta mendorong dan menginspirasi peserta didik nantinya berpikir secara kritis, analitis dan tepat dalam memecahkan masalah serta mengaplikasikan materi pembelajaran, menutun siswa untuk mencari tahu bukan diberitahu. Kurikulum 2013 ini memberikan 3 alternatif model pembelajaran yaitu Discovery Learning / Inkuiri, Problem Based Learning, dan Project Based Learning [4].

Model pemebelajaran berbasis masalah adalah salah satu model pembelajaran yang dapat memebrikan kondisi belajar aktif kepada peserta didik. Model pembelajaran ini dapat melibatkan peserta didik untuk memecahkan masalah dengan tahap - tahap metode ilmiah sehingga peserta didik dapat mempelajari pengetahuan yang berhubungan dengan masalah dan memiliki keterampilan untuk memecahkan masalah [5].

Untuk mencapai keberhasilan selain model pembelajaran yang tepat sebaiknya ditambah dengan media pembelajaran. Supaya proses belajar mengajar menarik dan dapat menumbuhkan kerjasama peserta didik maka dari itu model pembelajaran berbasis masalah dapat dipadukan dengan media pemebelajaran [2].

Terdapat beberapa penelitian yang berkaitan dengan model pembelajaran berbasis masalah dan penggunaan media powerpoint yang telah dilakukan yaitu, penelitian yang telah dilakukan oleh Novita Rose Diane [6] Pengaruh Metode Jigsaw disertai media lks Dan power point pada pembelajaran kimia Ditinjau dari kreativitas terhadap prestasi Belajar siswa pada materi pokok Hidrokarbon kelas x semester genap Di sma negeri 1 ponorogo T.a. 2011/2012 terdapat peningkatan prestasi belajar. Peneltian yang telah dilakukan oleh Yunin Nurun Nafiah [7] Penerapan Model Problem-Based Learning Untuk Meningkatkan Keterampilan Berpikir Kritis Dan Hasil Belajar Siswa dalam penelitian ini mengalami peningkatan hasil belajar sebesar 31,03\%. Penelitian yang telah dilakukan Yussi Pratiwi [8] Pelaksanaan Model Pembelajaran Problem Based Learning (Pbl) Pada Materi Redoks Kelas X SMA Negeri 5 Surakarta Tahun Pelajaran 2013/2014, megalami peningkatan hasil belajar siswa. Dan penelitian yang telah dilakukan Saifudin [9] dengan berjudul "Upaya Meningkatkan Hasil Belajar Siswa Dengan Menggunakan Model Pembelajaran Problem Based Learning (PBL) Pada Materi Kimia dengan hasil ketuntasan mencapai $86,49 \%$ dengan jumlah siswa 32 siswa dan yang tidak tuntas sebanyak 13,51\% dengan jumlah siswa 5 orang.

Oleh karena itu, implementasi model pembelajaran berbasis masalah menggunakan powerpoint dalam penelitian ini diharapkan dapat memberi kemudahan bagi siswa untuk memahami materi stoikiometri pada pelajaran kimia dan menigkatkan hasil belajar siswa.

\section{Metode}

Tempat dan Waktu Penelitian. Penelitian ini dilaksanakan di Sekolah Menengah Atas (SMA) Negeri 1 Stabat, yang berada di Kec. Stabat Kabupaten Langkat Provinsi Sumatera Utara, pada bulan April sampai dengan Mei 2015.

Desain Penelitian. Dalam penelitian ini sampel diambil dengan menggunakan teknik sampling purposif, atau penentuan sampel karena alasan tertentu. Adapun sampel yang diambil yaitu, dua kelas yang diajarkan oleh guru yang sama, jumlah jam pelajaran yang sama tetapi jadwal belajar yang berbeda. Untuk kelas eksperimen yaitu kelas X MIA 5 sebanyak 40 siswa, yang dibelajarkan dengan menggunakan model pembelajan berbasis masalah dan kelas kontrol yaitu X MIA 6 sebanyak 40 siswa, yan dibelajarkan dengan menggunakan model pembelajaran secara konvensional. 
Populasi dan Sampel. Dalam penelitian ini populasinya yaitu seluruh siswa kelas X MIA SMA NEGERI 1 STABAT semester II (genap), tahun ajaran 2014/2015 sebanyak \pm 250 orang siswa, yang terdiri dari 6 kelas.

Pengumpulan dan Analisis Data. Pada penelitian ini data dikumpulkan dari aspek pengetahuan. Data aspek pengetahuan didapat dari tes awal yang dilaksanakan sebelum pembelajaran. Kemudian Setelah perlakuan pengajaran, terhadap sampel siswa dilaksankan tes akhir. Data merupakan skor prestasi belajar siswa. Sebelum dilaksanakan tes, instrument tes telah diuji validitas, tingkat kesukaran dan daya bedanya.

\section{Hasil dan Pembahasan}

Berdasarkan hasil penelitian, setelah dilakukan perhitungan diperoleh hasil rata-rata pretest, posttest, dan simpangan baku. Seperti pada tabel 1 di bawah ini :

Tabel 1. Rata-rata dan Simpangan Baku

\begin{tabular}{|c|c|c|c|c|c|c|c|}
\hline \multicolumn{4}{|c|}{ Kelas Eksperimen } & \multicolumn{4}{|c|}{ Kelas Kontrol } \\
\hline \multicolumn{2}{|c|}{ Pretest } & \multicolumn{2}{|c|}{ Posttest } & \multicolumn{2}{|c|}{ Pretest } & \multicolumn{2}{|c|}{ Posttest } \\
\hline $\bar{X}$ & SD & $\bar{X}$ & SD & $\bar{X}$ & SD & $\bar{X}$ & SD \\
\hline 40 & 9.28 & 90.5 & 4.64 & 35.87 & 10.29 & 82.125 & 5.42 \\
\hline
\end{tabular}

Berdasarkan Tabel I, diperoleh rata-rata nilai pretest untuk kelas eksperimen adalah 40dengan nilai tertinggi 65 dan nilai terendah 25 dengan standart deviasinya 9.28. Sedangkan untuk nilai posttest diperoleh rata-rata nilai yaitu sebesar 90.5 dengan nilai tertinggi 100 dan nilai terendah 80 dengan standart deviasinya 4.64. Sementara rata-rata nilai pretest untuk kelas kontrol adalah 35.87 dengan nilai tertinggi 65 dan nilai terendah 20 dengan standart deviasinya 10.29. Sedangkan untuk nilai posttest diperoleh rata-rata nilai yaitu 8.125 dengan nilai tertinggi 95 dan nilai terendah 65 dengan standart deviasi 5.42 .

Berdasarkan hasil rata-rata pada Tabel 1, maka diperoleh grafik hasil belajar siswa pada Gambar 1 berikut:

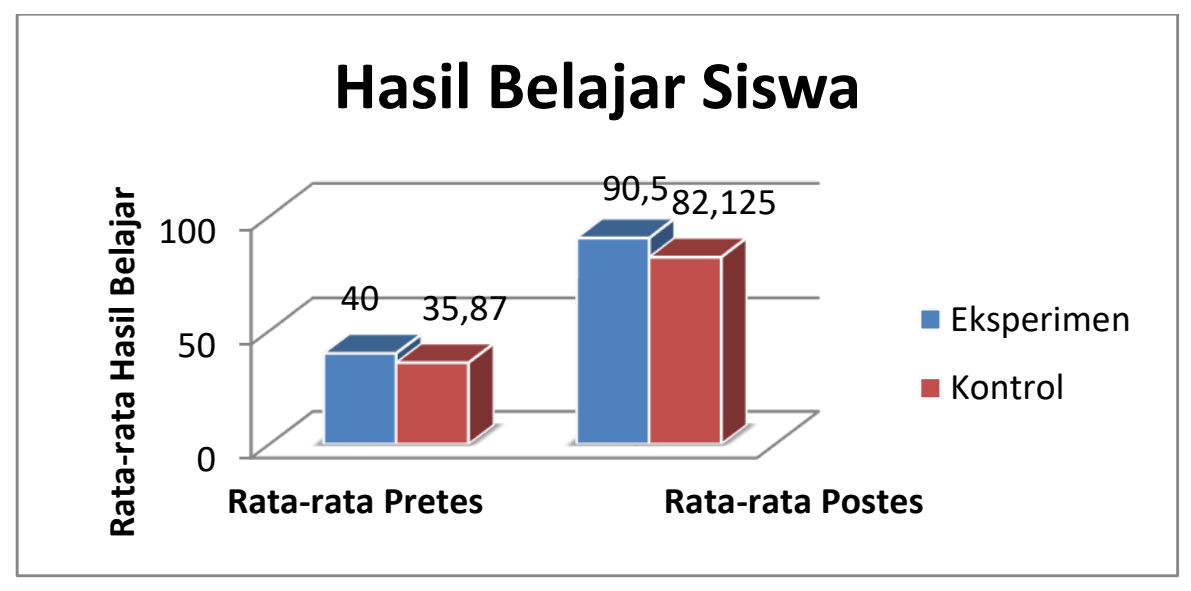

Gambar 1. Hasil Belajar siswa

\section{Peningkatan Hasil Belajar}

Hasil perhitungan persentase peningkatan hasil belajar dapat langsung dicari dari rata-rata nilai gain seluruh siswa untuk masing-masing kelas dapat dilihat pada Tabel 2. dibawah ini :

Tabel 2. Peningkatan Hasil Belajar

\begin{tabular}{|c|c|c|c|c|}
\hline Kelas & Kriteria & Ket : & $\mathrm{G}$ & Keterangan \\
\hline Eksperimen & $\mathrm{G}<0.3=$ Rendah & $\begin{array}{c}\sum g=33.19 \\
\sum \bar{g}=0.83\end{array}$ & $83 \%$ & Tinggi \\
\hline Kontrol & $\begin{array}{c}0.3<\mathrm{G}>0.1=\text { Sedang } \\
\mathrm{G}>0.7=\text { Tinggi }\end{array}$ & $\begin{array}{c}\Sigma \mathrm{g}=27.425 \\
\sum \bar{g}=0.69\end{array}$ & $69 \%$ & Sedang \\
\hline
\end{tabular}


Berdasarkan data gain siswa yang diperoleh pada penelitian dan setelah data ditabulasikan maka diperoleh rata-rata, standar deviasi, dan varians dari data gain baik dari kelas eksperimen dan kelas kontrol seperti tabel 3.

Tabel 3. Rata-Rata dan Standar Deviasi Data Gain

\begin{tabular}{cccc}
\hline Kelas & $\begin{array}{c}\text { Nilai Rata }- \text { Rata } \\
\text { Gain }\end{array}$ & $\begin{array}{c}\text { Standar Deviasi } \\
\text { Gain }\end{array}$ & $\begin{array}{c}\text { Varian } \\
\text { Gain }\end{array}$ \\
\hline Eksperimen & 83 & 0.077 & 0.0059 \\
\hline Kontrol & 69 & 0.059 & 0.0035 \\
\hline
\end{tabular}

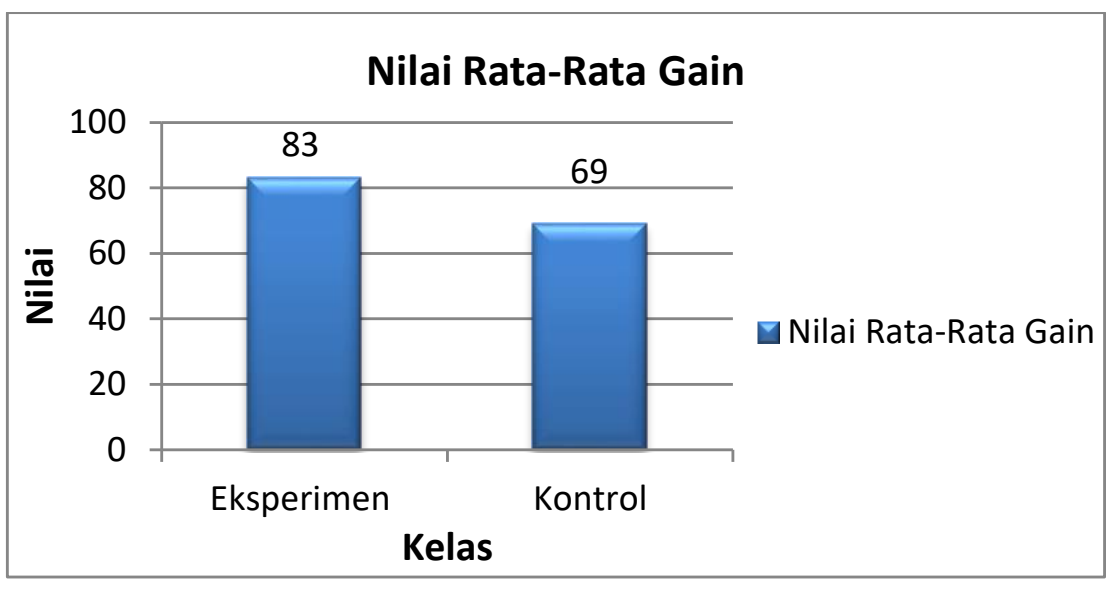

Gambar 2. Rata-Rata Nilai Gain

Berdasarkan analisis data perhitungan peningkatan hasil belajar siswa, di kelas eksperimen diperoleh peningkatan hasil belajar sebesar $83 \%$. Sedangkan peningkatan hasil belajar siswa di kelas kontrol diperoleh peningkatan hasil belajar sebesar 69\%. Jadi, perbedaan peningkatan hasil belajar siswa pada kelas eksperimen dengan kelas kontrol adalah $14 \%$.

\section{Kesimpulan}

Kesimpulan yang diperoleh dari penelitian yang telah dilaksanakan yaitu, mengalami peningkatan hasil belajar kimia pada siswa yang dibelajarkan dengan menerapkan model pembelajaran berbasis masalah dengan menggunakan media powerpoint dengan hasil yang lebih tinggi yaitu $83 \%$, sedangkan pada siswa yang dibelajarkan dengan pembelajaran konvensional yaitu, $69 \%$.

\section{Referensi}

[1] Wasonowati,R.R.T., Redjeki T., \& Ariani, S.R.D., 2014. Penerapan Model Problem Based Learning (PBL) pada Pembelajaran Hukum Hukum Dasar Kimia Ditinjau dari Aktivitas dan Hasil Belajar Siswa Kelas X IPA SMA Negeri 2 Surakarta Tahun Pelajaran $2013 / 2014$. Jurnal Pendidikan Kimia (JPK), 3: 66-75.

[2] Nugraha, Dian Anita.,2013.Efektivitas Metode Pembelajaran Kooperatif Think Pair Share (TPS) yang Dilengkapi Media Kartu Berpasangan (Index Card Match) Terhadap Prestasi Belajar Siswa pada Materi Ikatan Kimia Kelas X Semester Gasal SMA N 2 Karanganyar Tahun Pelajaran 2012/2013, Skripsi, FMIPA, UNS, Surakarta.

[3] Setiawan, Dwi Arief.,Elfi Susanti VH., Sri Mulyani., 2013.Prestasi Belajar dengan Pembelajaran Kooperatif Tipe Numbered Heads Together (NHT) Lebih Tinggidaripada Think-Pair-Share (TPS) pada Materi Pelajaran Tata Nama Senyawa Kimia dan Persamaan Reaksi Kimia, Jurnal Pendidikan Kimia Universitas Sebelas Maret (JPK), 2:11-18.

[4] Divisi PLPG Rayon 102.,2013.BukuKurikulum 2013, Universitas Negeri Medan Press, Medan.

[5] Ngalimun,2013.Strategi dan Model Pembelajaran, Aswaja Pressindo, Yogyakarta

[6] Diana, Novita Rose.,J.S. Sukardjo., Kus Sri Martini.,2013. Pengaruh Metode Jigsaw disertai media lks Dan power point pada pembelajaran kimia Ditinjau dari kreativitas terhadap prestasi Belajar siswa pada materi pokok Hidrokarbon kelas x semester genap Di sma negeri 1 ponorogo T.a. 2011/2012.Jurnal pendidikan UNS. 2:49-58.

[7] Nafiah,Yunin Nurun, 2014.Penerapan Model Problem-Based Learning Untuk Meningkatkan Keterampilan Berpikir Kritis Dan Hasil Belajar Siswa.Jurnal Pendidikan Vokasi,4:125-143. 
[8] Pratiwi, Yussi.,Tri Redjeki., Mohammad Masykuri., 2014.Pelaksanaan Model Pembelajaran Problem Based Learning (Pbl) Pada Materi Redoks Kelas X Sma Negeri 5 Surakarta Tahun Pelajaran 2013/2014.Jurnal Pendidikan Kimia,3:40-48.

[9] Saifudin, A., 2010. Upaya Meningkatkan Hasil Belajar Kimia Siswa Dengan Menggunakan Model Pembelajaran Problem Based Learning (PBL) (Penelitian Tindakan Kelas di MAN 12 Jakarta),FITK, UIN Syarif Hidayatullah, Jakarta.

[10] Chintya, Nana., Bakti Mulyani., Ashadi., 2017. Penerapan Model Pembelajaran Numbered Heads Together (NHT) Dikombinasi dengan Direct Instruction (DI) Berbantuan Catatan Terbimbing Untuk Menigkatkan Interaksi Sosial dan Prestasi Belajar pada Materi Kelarutan dan Hasil Kali Kelarutan Kelas XI MIPA 2 SMA Al-Islam 1 Surakarta tahun Pelajaran 2015/2016. Jurnal Pendidikan Kimia, 6:56-53

[11] Takziah, Fitria Izza., Sri Yamtinah., Haryono., 2017. Pengembangan Subject Specific Pedagogy (SSP) IPA terpadu Berbasis Model Ikuiri Terbimbing pada Tema Pemanasan Global untuk Meningkatkan Keterampilan Proses SAINS (KPS) Siswa SMP Kelas VII di Surakarta tahun Pelajaran 2015/2016. Jurnal Pendidikan Kimia, 6:119-127 